\title{
GASTROINTESTINAL DIGESTION OF KAHAI PROTEIN CONCENTRATE (CARYODENDRON ORINOCENSE KARST)
}

\author{
GREFFA $J^{2}$, BARRIONUEVO ${ }^{1}{ }^{1}$, VILCACUNDO $\mathrm{E}^{1}$, CARRILLO $\mathrm{W}^{1 *}$
}

${ }^{1}$ Research Department, Bolívar State University, Campus Laguacoto, Guaranda, Ecuador. ${ }^{2}$ Department of Research, Escuela Superior del Chimborazo, Panamericana Sur km 1 1/2, Riobamba, Ecuador. Email: wcarrillo@ueb.edu.ec/wi.carrillo@uta.edu.ec

Received: 31 May 2017, Revised and Accepted: 26 March 2018

\section{ABSTRACT}

Objective: The aim of this study was to obtain kahai protein concentrate from Caryodendron orinocense karst cultivated in the region Amazonia of Ecuador and characterizes its gastric and duodenal hydrolysates using the sodium dodecyl sulfate-polyacrylamide gel electrophoresis (SDS-PAGE) electrophoresis method and the reversed-phase ultra-high-performance liquid chromatography (RP-UHPLC) method.

Methods: Kahai seeds (C. orinocense karst) were utilized to obtain kahai protein concentrate at $\mathrm{pH} 5.0$ using the isoelectric precipitation method and then subject to gastric hydrolysis with pepsin enzyme $\left(2000 \mathrm{U} / \mathrm{mg}\right.$ of protein) at $\mathrm{pH} 1.2, \mathrm{pH} \mathrm{2.0}$, and $\mathrm{pH} 3.2$ at $37^{\circ} \mathrm{C}$ for $2 \mathrm{~h}$ with agitation in simulated gastric fluids and then to duodenal hydrolysis with pancreatin (mix enzymes) at $\mathrm{pH} 7.0$ at $37^{\circ} \mathrm{C}$ for $3 \mathrm{~h}$ with agitation in simulated intestinal fluid. Gastric and duodenal hydrolysates from kahai were characterized using the SDS-PAGE electrophoresis method and the RP-UHPLC chromatography method.

Results: Proteins obtained from kahai (C. orinocense karst) were hydrolyzed with pepsin, only one protein with molecular weight of $100 \mathrm{kDa}$ presented resistance to hydrolysis with pepsin at all pHs assayed. All proteins from kahai protein concentrate were totally hydrolyzed with pancreatin in in vitro conditions.

Conclusion: This study suggests that kahai protein concentrates have a high grade of digestibility in vitro when using the gastroduodenal model of digestion. Kahai protein can be a good source of alternative vegetal proteins to be consumed by animals and humans.

Keywords: Kahai, Proteins, Hydrolysis, Kahai protein concentrate, Pepsin, Pancreatin.

(C) 2018 The Authors. Published by Innovare Academic Sciences Pvt Ltd. This is an open access article under the CC BY license (http://creativecommons. org/licenses/by/4. 0/) DOI: http://dx.doi.org/10.22159/ajpcr.2018.v11i6.20374

\section{INTRODUCTION}

Caryodendron orinocense Karst is a native fruit of the Amazonic region belonging to the family Euphorbiaceae, this plant has about 60 genus and 529 species [1], namely, kahai, inchi, and nuez de barinas. This fruit has a high content of proteins $(17.78 \%$, lipids $(28.29 \%)$, and carbohydrates $(34.60 \%)[2,3]$. Lipid from kahai seeds are used to elaborate different products pharmaceutics and cosmetics, but its proteins are not used. The indigenous of Amazonia of Ecuador and Colombia have used kahai oil in the preparation of ointments and differentfoods. Different Amazonic fruits have a high content of lipids such as Sacha inchi (Plukenetia volubilis) and Ungurahui (Oenocarpus bataua). After the extraction of oil, a byproduct named (tort or flour) is obtained, this byproduct is rich in protein [4-6]. This byproduct can be used to feeding and animal or human nutrition for their qualities. In the food industry, different hydrolysates are used for their functional properties such as hydrolysate of soybean, hydrolysate of whey protein, and hydrolysate of caseins [7,8]. Hydrolysate of soybean is used in the infant formula milks for their high digestibility and good composition of amino acids [8,9]. In the literature, different hydrolysates obtained from vegetable proteins have been described. Among them are quinoa, amaranth, sesamo, macadamia, sacha inchi, chia and tocte [9-18]. The aim of this study was to obtain kahai protein concentrate from C. orinocense karst cultivated in the region Amazonia of Ecuador and characterizes its gastric and duodenal hydrolysates using the sodium dodecyl sulfate-polyacrylamide gel electrophoresis (SDS-PAGE) electrophoresis method and the reversed-phase ultra-high-performance liquid chromatography (RP-UHPLC) method.

\section{METHODS}

Protein concentrate obtained from kahai flour

Kahai protein concentrate was prepared according to Martínez and Añón [19] with modifications. The defatted flour was suspended in water in a $1: 10 \mathrm{w} / \mathrm{v}$, and the suspension was adjusted to $\mathrm{pH} 8.0$ by adding $2 \mathrm{M}$ $\mathrm{NaOH}$. The suspension was stirred during $1 \mathrm{~h}$ and then centrifuged at $4500 \mathrm{~g}$ for $30 \mathrm{~min}$ at $25^{\circ} \mathrm{C}$. The supernatant was adjusted to $\mathrm{pH} 5.0$ with 2 $\mathrm{N} \mathrm{HCl}$ and centrifuged for $20 \mathrm{~min}$ at $4500 \mathrm{~g}$. The pellet was suspended in a small volume of water, neutralized with $0.1 \mathrm{M} \mathrm{NaOH}$, and lyophilized, and then frozen at $-20^{\circ} \mathrm{C}$. The content of protein in kahai protein concentrate was determined using the bicinchoninic acid (BCA) and Dumas methods with values of $50.65 \%$ and $48.32 \%$, respectively $[20,21]$.

\section{SDSPAGE analysis}

SDS-PAGE of kahai protein concentrate was analyzed according to the method proposed by Laemmli [22]. The SDS-PAGE system uses $12 \%$ polyacrylamide gel $/ 100 \mathrm{~mL}$ of resolving gel; $4 \mathrm{~g}$ acrylamide/100 mL of stacking gel was used in a Mini-Protean Tetra Cell electrophoresis system (Bio-Rad, Hercules, CA, USA) with the run of $220 \mathrm{~V}$ constant during $30 \mathrm{~min}$. Polypeptide bands were stained in Coomassie Brilliant Blue G-250 for $12 \mathrm{~h}$. Relative molecular masses of proteins were determined by comparison to molecular weight markers 6.5-200 kDa kaleidoscope prestained standards (Bio-Rad) containing myosin (198 kDa), $\beta$-galactosidase (125 kDa), BSA (88 kDa), carbonic anhydrase (37 kDa), STI (31 kDa), LYS (17 kDa), and aprotinin (6.5 kDa). Molecular weight calibration kit for SDS electrophoresis (GE Healthcare, Uppsala, Sweden) containing phosphorylase B (97 kDa), BSA (66 kDa), OVA (45 kDa), carbonic anhydrase (37 kDa), trypsin inhibitor (20.1 kDa), and LA (14.4 kDa) was used. Polypeptide bands were stained in Coomassie Brilliant Blue G-250 for $12 \mathrm{~h}$ with constant agitation. Then, the gels were washed out with a solution of methanol with acetic acid.

Gastric and duodenal digestion of kahai protein concentrate Kahai Protein Concentrate obtained at pH $5.0(10 \mathrm{mg} / \mathrm{ml})$ was subjected at simulation gastrointestinal digestion. The environment of the stomach and duodenum was reproduced as close as possible. 
This study uses a model which emulates the environment of human gastrointestinal tract with its $\mathrm{pH}$, the presence of enzymes, bile salts, temperature, and movement.

\section{Gastric digestion}

We used pepsin in a concentration of $2.000 \mathrm{U} / \mathrm{ml}$ of sample of protein at different pHs: $\mathrm{pH} 1.2, \mathrm{pH} 2.0$, and $\mathrm{pH} 3.2$ in (simulated gastric fluid [SGF] $0.35 \mathrm{M} \mathrm{NaCl}$ ), for $2 \mathrm{~h}$ at $37^{\circ} \mathrm{C}$ with agitation. The pepsin reaction was stopped with heat at $90^{\circ} \mathrm{C}$ for $10 \mathrm{~min}$. After the hydrolysates were lyophilized and stored at $-20^{\circ} \mathrm{C}$

\section{Duodenal digestion}

We used pancreatin in a concentration of $100 \mathrm{U} / \mathrm{ml}$ of sample protein in simulated intestinal fluid (SIF). The composition is a monobasic potassium phosphate solution of pancreatin with bile salt $10 \mathrm{~mm}$ and $\mathrm{CaCl} 21.5 \mathrm{M} .1 \mathrm{~mL}$ of gastric digestion at $\mathrm{pH} 1.2, \mathrm{pH} 2.0$, and $\mathrm{pH} 3.2$ was mixed with $1 \mathrm{~mL}$ of solution of pancreatin in medium SIF for $3 \mathrm{~h}$ at $37^{\circ} \mathrm{C}$ with agitation. The reaction was stopped with heat at $90^{\circ} \mathrm{C}$ for $10 \mathrm{~min}$. After the hydrolysates were lyophilized and stored at $-20^{\circ} \mathrm{C}$.

\section{Analysis of hydrolysates from kahai protein concentrate using RP- UHPLC}

Gastric and duodenal hydrolysates of kahai lyophilized were analyzed using RP-UHPLC on Agilent 1200 infinity series UHPLC system (Agilent Technologies, Waldbronn, Germany). The variable wavelength detector was $214 \mathrm{~nm}$. The column used was EC C18 (Agilent Poroshell 120, 4.6 $\times 50 \mathrm{~mm} \times 2.7 \mu \mathrm{m}$ of particle size). Samples were eluted at $1.0 \mathrm{~mL} / \mathrm{min}$ with a linear gradient from $0 \%$ to $70 \%$ of solvent B (acetonitrile and trifluoroacetic acid [TFA], $1000: 0.270 \mathrm{v} / \mathrm{v}$ ) in solvent A (water and TFA, 1000: $0.370 \mathrm{v} / \mathrm{v}$ ) during $10 \mathrm{~min}$. The injection volume was $100 \mu \mathrm{L}$ for each duplicated sample.

\section{RESULTS}

\section{SDS-PAGE electrophoresis analysis of gastric digestion}

The gastric hydrolysates of kahai protein concentrate at $\mathrm{pH} 1.2 ; \mathrm{pH} 2.0$, and $\mathrm{pH} 3.2$ hydrolyzed with pepsin were analyzed using SDS-PAGE electrophoresis in reducing conditions (2-mercaptoethanol). Proteins of kahai were hydrolyzed with pepsin at $\mathrm{pH} 1.2, \mathrm{pH} 2.0$, and $\mathrm{pH} 3.2$. Only one protein presented resistance at the hydrolysis with pepsin at all $\mathrm{pHs}$ assayed. This protein presented high molecular weight with approximate $100 \mathrm{kDa}$ (Fig. 1).

\section{SDS-PAGE electrophoresis analysis of duodenal digestion}

The gastric hydrolysates of kahai protein at $\mathrm{pH} 1.2, \mathrm{pH} 2.0$, and $\mathrm{pH} 3.2$ hydrolyzed with pepsin were subject to duodenal hydrolysis with pancreatin at $\mathrm{pH}$ 7.0. After hydrolysis, the digestion of kahai was analyzed using SDS-PAGE electrophoresis in reducing conditions (2-mercaptoethanol). All proteins of kahai protein concentrate were hydrolyzed with pancreatine (duodenal digestion). Proteins from kahai have a high digestibility in in vitro conditions (Fig. 2).

\section{RP-UHPLC chromatography analysis of gastro-duodenal hydrolysis} of kahai

Gastric and duodenal hydrolysates of kahai were analyzed with the RP-UHPLC method. Kahai protein concentrate obtained at $\mathrm{pH} 5.0$ isoelectric precipitation without hydrolysis was used as comparative control (Fig. 3e). Kahai protein concentrate presents four majoritarian fractions. Kahai gastric hydrolysate at $\mathrm{pH} 1.2, \mathrm{pH} 2.0$, and $\mathrm{pH} 3.2$ presents similar profile of fractions (peptides) (Fig. 3ac). Only kahai gastric hydrolysate at $\mathrm{pH} 3.2$ presented less intensity in the chromatogram. The first and the second fractions (F1 and F2) presented resistance to hydrolysis with pepsin. This result is in accordance with the SDS-PAGE electrophoresis analysis as in the gel we observe one band of protein without hydrolysis. The third and the fourth fractions were totally hydrolyzed with the pepsin enzyme in in vitro conditions. Kahai duodenal digestion was analyzed, and we can observe that the four fractions were hydrolyzed with pancreatin because the profile is different. All peaks presented different retention

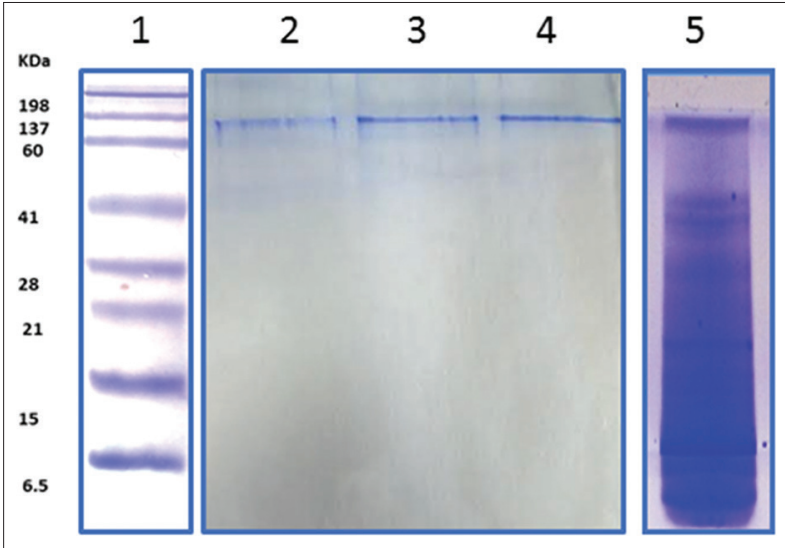

Fig. 1: Sodium dodecyl sulfate-polyacrylamide gel electrophoresis analysis of gastric hydrolysates of kahai. Line 1: Standard molecular weight, Line 2: Kahai gastric digestion at $\mathrm{pH}$ 1.2, Line 3: Kahai gastric digestion at pH 2.0, Line 4: Kahai gastric digestion at pH 3.2, and Line 5: Kahai protein concentrate obtained at pH 5.0 of precipitation without hydrolysis

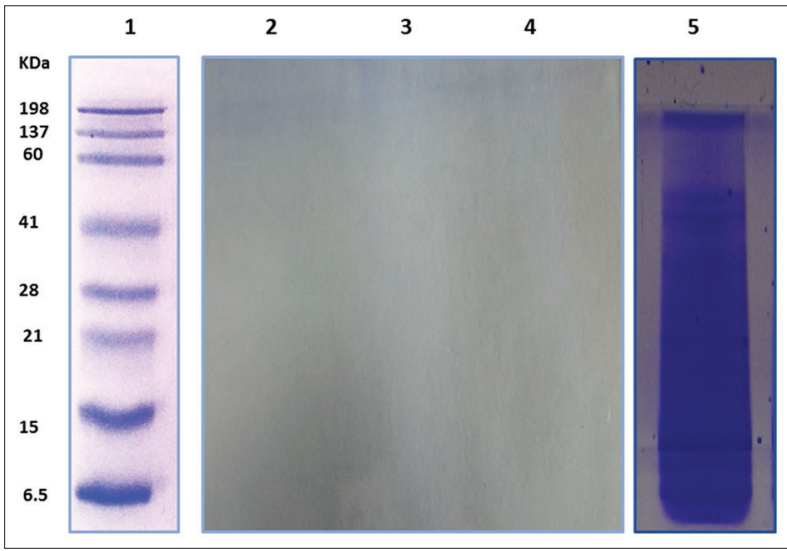

Fig. 2: Sodium dodecyl sulfate-polyacrylamide gel electrophoresis analysis of duodenal digestion of kahai. Line 1: Standard molecular weight, Line 2: Kahai duodenal digestion of gastric digestion of $\mathrm{pH} 1.2$, Line 3: Kahai duodenal digestion of gastric digestion of $\mathrm{pH}$ 2.0, Line 4: Kahai duodenal digestion of gastric digestion of $\mathrm{pH}$ 3.2, and Line 5: Kahai protein concentrate obtained at $\mathrm{pH} 5.0$ of precipitation without hydrolysis

times when compared to retention times of fractions of gastric digestion (Fig. 3d)

\section{DISCUSSION}

Vegetal proteins are being the object of many studies to evaluate their use such as source of protein isolate and protein concentrate. Soy protein isolate is the product more used in the food industry for different purposes such as infant formula, nutraceutics products, functional foods, milks, and beverages [23-25]. There is extensive research looking for new sources of vegetal proteins (amaranto, quinoa, pea, and lupinus). Digestibility of animal and plant proteins is very important for their use in the food industry, pharmaceutical, and medical purposes. Plant proteins present high digestibility in in vitro and in vivo conditions. For this reason, plant proteins are more consumed and recommended for children and adults [26]. Furthermore, it is important to know their content of possible allergens. The allergens present a high resistance to hydrolysis in vitro with pepsin. For this reason, the FAO and WHO recommend assays in vitro of the digestibility with pepsin to predict the presence of possible allergens in the foods. Hen proteins have been evaluated as allergens with assays of digestion in vitro with pepsin using $\mathrm{SFG}$, this method being recommended by American pharmacopeia. 


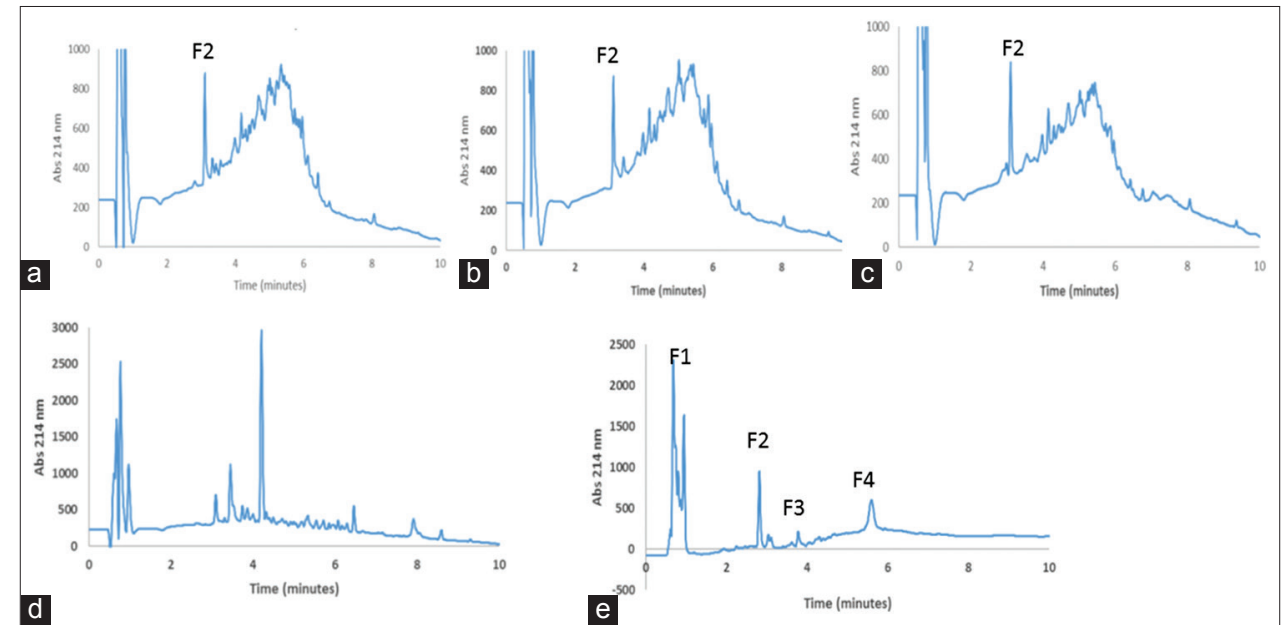

Fig. 3. Reversed-phase ultra-high-performance liquid chromatography analysis of gastric and duodenal digestion of kahai protein concentrate. (a) Gastric digestion of kahai protein at pH 1.2, (b) gastric digestion of kahai protein at pH 2.0, (c) gastric digestion of kahai protein at $\mathrm{pH} 3.2$, (d) duodenal digestion of kahai protein, and (e) kahai protein concentrate obtained at pH 5.0 of precipitation. Column Zorbax EC C18 (Agilent Poroshell 120, $4.6 \times 50 \mathrm{~mm} \times 2.7 \mu \mathrm{m}$ of particle size). 0\% B-70\% B (ACN+TFA) in $10 \mathrm{~min}$

Astwood et al. [27] reported a relation between the stability of a protein in SGF and its status as a food allergen. SGF is defined as reagents held under specific conditions $\left(0.32 \%\right.$ pepsin, $\left.\mathrm{pH} 1.2,37^{\circ} \mathrm{C}\right)$ and was developed to represent human gastric conditions in the stomach of a healthy adult. Lysozyme and ovoalbumine from hen chicken were evaluated with digestion in vitro with pepsin, presenting resistance to hydrolysis with pepsin. One characteristic of food allergens is the resistance to gastrointestinal hydrolysis [28-30].

Kahai protein concentrate presents a high grade of digestibility with pepsin and pancreatin when used in in vitro conditions. Only one protein presents resistance to hydrolysis with pepsin but was hydrolyzed with pancreatin. It is probable that kahai proteins have no allergens. These kahai hydrolysates can have bioactive peptides. Future research could evaluate different biological activities and possibly identify the sequence of bioactive peptides from kahai seeds. In the developed countries, the consume of vegetal proteins is a good alternative of good proteins, vegetal protein is cheaper, and their quality is excellent. Some vegetal proteins have a good amino acids composition such as amaranth and quinoa. New sources of vegetal proteins are necessary to evaluate their digestibility to find out their possible allergenicity.

\section{CONCLUSIONS}

Kahai protein concentrate presents high in vitro digestibility with pepsin and pancreatin enzymes using the SGF and SIF methods of hydrolysis, these methods are recommended to assay the in vitro digestibility. It is possible that kahai seeds have no allergens proteins. Gastric and duodenal hydrolysates from kahai can have bioactive peptides that can be used to elaborate functional foods and nutraceuticals products. Kahai seeds can be a good source of proteins to countries in development such as Ecuador and a good crop to indigenous for their high contents of lipids and proteins.

\section{REFERENCES}

1. Alfaro Mde J, Alvarez I, El Khor S, de Padilla FC. Functional properties of a protein product from Caryodendron orinocense (Barinas nut). ALAN 2004;54:223-8.

2. Alfaro JM. Physico-chemical characteristics of the Barinas nut (Caryodendron orinocense Karst. Euphorbiaceae) crude oil. ALAN 1994;44:172-5.

3. Perez RM, Alfaro MJ, Padilla FC. Evaluation of "nuez barinas"(Caryondredon orinocense) oil for possible use in cosmetic. Int J Cosmetic Sci 1999;21:151-8.

4. Sathe SK, Hamaker BR, Sze-Tao KW, Venkatachalam M. Isolation, purification, and biochemical characterization of a novel water soluble protein from inca peanut (Plukenetia volubilis L.). J Agric Food Chem 2002;50:4906-8

5. Darnet SH, Silva LH, Rodrigues AM, Lins RT. Nutritional composition, fatty acid and tocopherol contents of buriti (Mauritia flexuosa) and patawa (Oenocarpus bataua) fruit pulp from the Amazon region. Food Sci Technol Camp 2011:31:488-91.

6. Carrillo W, Carpio C, Morales D, Alvarez M, Silva M. Fatty acids content in ungurahua oil (Oenocarpus bataua) from Ecuador. Findings on adulteration of ungurahua oil in Ecuador. Asian J Pharm Clin Res 2018;11:391-4.

7. Carrillo W, Monteiro KM, Martínez-Maqueda D, Ramos M, Recio I, Carvalho JE. Antiulcerative activity of milk proteins hydrolysates. J Med Food 2018;21:408-15.

8. Carrillo W, Monteiro KM, Spindola H, Ramos M, Carvalho JE. Antiulcerative and antinociceptive activities of casein and whey proteins. J Med Food 2018. DOI: 10.1089/jmf.2017.0090.

9. Vilcacundo R, Barrio D, Carpio C, García-Ruiz A, Rúales J, HernándezLedesma B, et al. Digestibility of quinoa (Chenopodium quinoa Willd.) protein concentrate and its potential to inhibit lipid peroxidation in the zebrafish larvae model. Plant Foods Hum Nutr 2017;72:294-300.

10. Vilcacundo R, Miralles B, Carrillo W, Hernández-Ledesma B. In vitro chemopreventive properties of peptides released from quinoa (Chenopodium quinoa Willd.) protein under simulated gastrointestinal digestion. Food Res Int 2018;105:403-11.

11. Hu M, McClements DJ, Decker EA. Lipid oxidation in corn oil-in water emulsions stabilized by casein, whey protein isolate, and soy protein isolate. J Agric Food Chem 2003;51:1696-700.

12. Drapala KP, Auty MA, Mulvihill DM, O’Mahony JA. Improving thermal stability of hydrolysed whey protein-based infant formula emulsions by protein-carbohydrate conjugation. Food Res Int 2016;88:42-51.

13. Acosta C, Carpio C, Vilcacundo R, Carrillo W. Identification of proteins isolate from amaranth (Amaranthus caudatus) by sodium dodecyl sulfate-polyacrylamide gel electrophoresis with water and $\mathrm{NaCl} 0.1 \mathrm{~m}$ solvents. Asian J Pharm Clin Res 2016:9:331-3.

14. Poveda T, Vilcacundo R, Carpio C, Carrillo W. Analysis of sesame proteins isolate (Sesamum indicum L) with water and salt treatment. Asian J Pharm Clin Res 2016;9:404-7.

15. Toapanta A, Carpio C, Vilcacundo R, Carrillo W. Analysis of protein isolate from quinoa (Chenopodium quinoa Willd). Asian J Pharm Clinical Res 2016;9:332-4.

16. Quinteros MF, Vilcacunco R, Carpio C, Carrillo W. Isolation of proteins from sacha inchi (Plukenetia volubilis L.) in presence of water and salt. Asian J Pharm Clin Res 2016;9:193-6.

17. Lara D, Vilcacundo E, Carrillo C, Carpio C, Silva M, Alvarez M, et al. Obtention of protein concentrate and polyphenols from macadamia (Macadamia integrifolia) with aqueous extraction method. Asian J Pharm Clin Res 2017;10:303-6.

18. Carrillo W, Gómez-Ruiz JA, Ruiz AL, Carvalho JE. Antiproliferative activity of walnut (Juglans regia L.) proteins and walnut protein hydrolysates. J Med Food 2017;20:1063-7. 
19. Martínez NE, Añón MC. Composition and structural characterization of amaranth protein isolates. An electrophoretic and calorimetric study. J Agric Food Chem 1996;44:2523-30.

20. Krieg RC, Dong Y, Schwamborn K, Knuechel R. Protein quantification and its tolerance for different interfering reagents using the BCA method with regard to 2D SDS PAGE. J Biochem Biophys Methods 2005;65:13-9.

21. Serrano S, Rincón F, García-Olmo J. Cereal protein analysis via dumas method: Standardization of a micro-method using the Euro vector elemental analyser. J Cereal Sci 2013;58:31-6.

22. Laemmli UK. Cleavage of structural proteins during the assembly of the head of bacteriophage T4. Nature 1970;227:680-5.
23. Maubois JL, Lorient D. Dairy proteins and soy proteins in infant foods nitrogen-to-protein conversion factors. Dairy Sci Technol 2016;96:15-25.

24. Brahim A, Addou S, Merzouk A, Kh Éroua O, Saidi D. Antigenicity of hydrolyzed rice formula in animal model (BALB/C MICE). Int J Pharm Pharm Sci 2014;6:352-4

25. Molina E, Papadopoulou A, Ledward DA. Emulsifying properties of high pressure treated soy protein isolate and $7 \mathrm{~S}$ and $11 \mathrm{~S}$ globulins. Food Hydrocoll 2001;15:263-9.

26. Berghout JA, Venema P, Boom RM, Van der Goot AJ. Comparing functional properties of concentrated protein isolates with freeze-dried protein isolates from lupin seeds. Food Hydrocoll 2015;51:346-54. 